$\begin{array}{rr}\text { FIT(PPATOLOGI } & \text { Volume } 11, \text { Nomor 5, Oktober 2015 } \\ \text { IN D ONESIA } & \text { Halaman 159-165 } \\ \text { ISSN: } 0215-7950 & \text { DOI: } 10.14692 / \text { jfi.11.5.159 }\end{array}$

\title{
Ketahanan Lapangan Lima Genotipe Padi terhadap Penyakit Hawar Daun Bakteri
}

\author{
Field Resistance of Five Rice Genotypes to Bacterial Leaf Blight
}

\author{
Rezki Heru Aditya, Wiwiek Sri Wahyuni*, Paniman Ashna Mihardjo \\ Universitas Jember, Jember 68121
}

\begin{abstract}
ABSTRAK
Penyakit hawar daun bakteri (HDB) yang disebabkan oleh Xanthomonas oryzae pv. oryzae merupakan penyakit penting di Indonesia. Padi varietas Inpari 30, Situbagendit, Luk-ulo, dan Cibogo diketahui memiliki ketahanan terhadap penyakit HDB sehingga dapat digunakan untuk mengukur ketahanan galur padi baru. Penelitian dilakukan untuk mengevaluasi ketahanan lapangan galur padi baru, yaitu galur X yang memiliki ketahanan terhadap HDB. Penelitian dilakukan di Desa Wirolegi, Kecamatan Sumbersari, Kabupaten Jember dengan infeksi $X$. oryzae yang terjadi secara alami. Ketahanan tanaman diukur dengan nilai insidensi penyakit (IP) dan keparahan penyakit (KP). IP tertinggi (100\%) dicapai oleh semua varietas dan galur uji pada umur yang berbeda. Pada 90 hari setelah tanam, KP pada galur X mencapai 11.85\%, jauh lebih rendah dibandingkan dengan KP pada var. Situbagendit $(40.25 \%)$. Berdasarkan nilai KP dan IP, galur X memiliki ketahanan yang terbaik, yaitu tahan pada fase vegetatif dan agak tahan pada fase generatif. Namun, pada penelitian ini tidak diketahui galur $X$. oryzae yang menyerang varietas dan galur padi tersebut.
\end{abstract}

Kata kunci: galur padi, insidensi penyakit, keparahan penyakit, Xanthomonas oryzae pv.oryzae

\begin{abstract}
Bacterial leaf blight disease caused by Xanthomonas oryzae pv. oryzae is an important disease on rice in Indonesia. Four rice varieties, i.e. Inpari 30, Situbagendit, Luk-ulo and Cibogo has been known to have resistance to the disease. Therefore, they can be used as indicator plants to measure the resistance of any new rice genotypes to the disease. Research was aimed to evaluate field resistance of a new rice line, i.e. line $\mathrm{X}$, with 4 resistant rice varieties as check control. The research was conducted in the field in Wirolegi villages, Sumbersari-Jember with natural infection of $X$. oryzae. Plant resistance was observed by measuring disease incidence (DI) and severity (DS). The highest DI (100\%) was reached by all genotypes in different age. At 90 days after planting, DS of line X reached $11.85 \%$ which is far low compared to DS of var. Situbagendit $(40.25 \%)$. Based on DI and DS, line X is considered to have the best resistance to the disease, i.e. resistant in vegetative phase and moderately resistant in generative phase. However, the strain of $X$. oryzae infecting the plants in the field was unknown.
\end{abstract}

Key words: disease incidence, disease severity, rice line, Xanthomonas oryzae pv. oryzae

*Alamat penulis korespondensi: Jurusan Hama Penyakit Tumbuhan, Fakultas Pertanian, Universitas Jember, Kampus Tegal Boto. Jalan Kalimantan No. 37, Jember, 68121.

Tel: 0331-330224, Faks: 0331-339029, Surel: wiwiekwahyuni@gmail.com. 


\section{PENDAHULUAN}

Penyakit hawar daun bakteri (HDB) yang disebabkan oleh bakteri Xanthomonas oryzae pv. oryzae merupakan penyakit penting yang berpengaruh pada kehilangan hasil tanaman padi di Indonesia (Khaeruni et al. 2014). Balai Penelitian dan Pengembangan Pertanian melalui buku kalender tanam terpadu (BPPP 2014a), menyatakan bahwa penyakit ini sangat rawan. Penyakit ini dapat mengurangi mutu beras yang dihasilkan karena dapat menyerang pada semua fase pertumbuhan padi (Herlina dan Silitonga 2011).

Penggunaan varietas tahan merupakan salah satu cara pengelolaan penyakit HDB yang murah, mudah, efektif dan ramah lingkungan. Bakteri $X$. oryzae merupakan patogen yang mampu membentuk galur baru dengan cepat, hingga kini telah ditemukan 12 galur $X$. oryzae dengan tingkat virulensi yang berbeda. Serangan $X$. oryzae di Indonesia saat ini didominasi oleh galur IV dan VIII (Wahyudi et al. 2011). Pada tahun 19992010 pemerintah melepas varietas padi yang tahan terhadap penyakit HDB, di antaranya Cisantana, Ketonggo, Sintanur, dan Wera yang tahan terhadap $X$. oryzae galur III, serta Situbagendit yang agak tahan terhadap $X$. oryzae galur III dan IV (BPTP 2011).

Penanaman varietas baru yang tahan merupakan salah satu solusi untuk menghambat perkembangan penyakit HDB. Namun berbagai varietas baru banyak yang belum diketahui ketahanannya terhadap galur $X$. oryzae yang beragam. Oleh karena itu, pengujian kembali terhadap penyakit HDB perlu dilakukan.

\section{BAHAN DAN METODE}

Penelitian ini dilaksanakan di Desa Wirolegi, Kecamatan Sumbersari, Kabupaten Jember pada bulan Januari-April 2015. Padi varietas Inpari 30, Luk-ulo, Situbagendit, Cibogo, dan padi galur $\mathrm{X}$ ditanam dengan sistem jajar legowo (6:1) pada lahan yang tergolong sangat rawan terhadap penyakit HDB berdasarkan ramalan kalender tanam terpadu
(2014-2015). Padi galur X diperoleh dari Balai Besar Penelitian Tanaman Padi Subang. Proses budi dayanya mengikuti cara pada umumnya, namun tidak dilakukan pengendalian organisme pengganggu tumbuhan. Serangan $X$. oryzae dibiarkan terjadi secara alami.

\section{Pengambilan Sampel}

Pengambilan sampel padi pada setiap varietas dan galur dilakukan dengan metode diagonal random sampling. Setiap lahan terdapat 5 petak sampel yang berukuran $3 \mathrm{~m} \times 3 \mathrm{~m}$, di setiap petak tersebut ditentukan 18 rumpun secara acak sebagai tanaman sampel (10\% dari populasi tanaman). Pengamatan dilakukan dengan interval 7 hari, dimulai dari 20-90 hari setelah tanam (HST) dan dihitung jumlah anakannya untuk mengetahui hubungan kerapatannya dengan insidensi penyakit (IP) dan keparahan penyakit (KP).

\section{Insidensi Penyakit dan Keparahan Penyakit}

Insidensi penyakit dihitung menggunakan rumus:

$$
\mathrm{IP}=(\mathrm{n} / \mathrm{N}) \times 100 \% \text {, dengan }
$$

IP, insidensi penyakit (\%); N, jumlah rumpun yang diamati; $n$, jumlah rumpun yang terserang. Keparahan penyakit dihitung menggunakan rumus:

$$
\mathrm{KP}=[\Sigma(\mathrm{ni} \times \mathrm{vi}) /(\mathrm{V} \times \mathrm{N})] \times 100 \% \text {, dengan }
$$

$\mathrm{KP}$, keparahan penyakit (\%); ni, jumlah rumpun dengan skala i; vi, nilai skala penyakit dari i; $\mathrm{V}$, nilai skala tertinggi, $\mathrm{N}$, jumlah rumpun yang diamati. Skala kerusakan tanaman menurut IRRI (1994): 0 (tidak ada gejala), 1 (1-5\%), 3 (>5-12\%), 5 (>12-25\%), 7 (>25-50\%), $9(>50-100 \%)$.

\section{Kategori Ketahanan}

Berdasarkan pada nilai IP, ketahanan tanaman dikelompokkan sesuai kategori gejala penyakit sistemik, yaitu tahan (0-35\%), agak tahan (36-70\%), dan rentan (>70\%) (PCARRD 1985). Berdasarkan pada nilai KP, ketahanan tanaman dikategorikan sesuai standar evaluation system IRRI (1994), yaitu tahan $(1-5 \%)$, agak tahan $(>5-12 \%)$, agak rentan $(>12-25 \%)$, rentan $(>25-50 \%)$, sangat rentan $(>50 \%)$. 


\section{HASIL}

\section{Penyakit Hawar Daun Bakteri}

Gejala penyakit HDB ditemukan pada semua varietas dan galur yang diuji. Gejala pada fase vegetatif dimulai dari perubahan warna daun kekuningan kemudian menjadi abu-abu atau kering yang dimulai dari bagian tepi maupun ujung daun. Pada fase generatif gejala yang ditemukan ialah hawar (blight), yaitu daun berubah menjadi abu-abu pada bagian tepi daun, pada satu sisi daun, atau pada kedua sisi daun. Gejala ini sering dijumpai pada sepanjang tulang daun. Gejala pada fase ini cenderung sama dengan gejala pada fase vegetatif (Gambar 1).

\section{Xanthomonas oryzae pv. oryzae}

Bakteri memiliki koloni berwarna kuning, berbentuk mukoid, bulat dan cembung setelah ditumbuhkan pada medium yeast dextrose agar (YDA), sedangkan sel bakteri berbentuk batang dan bersifat Gram negatif. Hal tersebut memang belum mencerminkan bahwa bakteri tersebut ialah $X$. oryzae pv. oryzae. Jika ditinjau dari hasil isolasi biakan dan gejala penyakitnya maka isolat bakteri ialah $X$. oryzae pv. oryzae

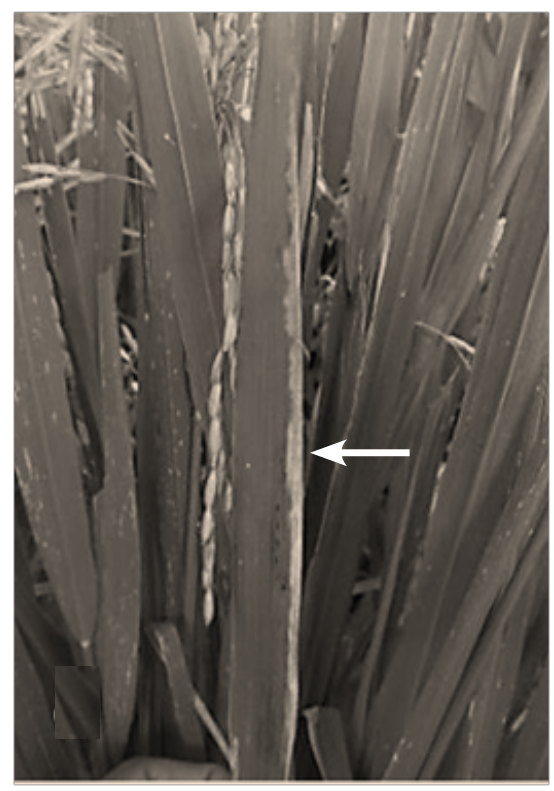

a

\section{Insidensi dan Keparahan Penyakit}

Sejak 20 HST, semua varietas dan galur padi yang diuji ketahanannya terhadap penyakit HDB mempunyai nilai IP $>5 \%$ dan $\mathrm{KP}>1 \%$ dan terus meningkat sampai hari ke90 (Gambar 2 dan 3). IP 100\% dicapai varietas Luk-ulo dan varietas Situbagendit secara berurutan pada 48 HST dan 55 HST, pada varietas Inpari 30 dan Cibogo nilai IP 100\% masing-masing dicapai pada 69 HST dan pada galur padi X nilai IP $100 \%$ dicapai pada $76 \mathrm{HST}$ (Gambar 2). Pada 90 HST, nilai KP galur padi $\mathrm{X}$ ialah $11.85 \%$, var. Inpari 30, Cibogo, Lukulo, dan Situbagendit secara berurutan ialah $20 \%, 20.85 \%, 39.75 \%$, dan 40.25\% (Gambar 3 ). Secara keseluruhan varietas maupun galur mempunyai nilai IP dan KP yang meningkat seiring dengan bertambahnya umur tanaman. Bahkan var. Luk-ulo pada 48 HST mempunyai IP $100 \%$ dan merupakan yang tercepat dari semua varietas dan galur padi yang diuji. Nilai KP juga naik pada 3 varietas yang diuji (Situbagendit, Luk-ulo, dan Cibogo) hingga mencapai ambang kerusakan (Gambar 2 dan 3). Sebaliknya galur padi X mempunyai nilai IP dan KP terendah serta membutuhkan waktu yang paling lama untuk mencapai nilai IP dan KP tersebut.

Gambar 1 Gejala penyakit hawar daun bakteri pada daun tanaman padi. a fase vegetatif, gejala yang dimulai dari tepian daun yang berubah keabu-abuan; $b$ fase generatif, gejala yang dimulai dari bagian ujung dan tepian tulang daun yang menjadi keabu-abuan dan mulai mengering. 


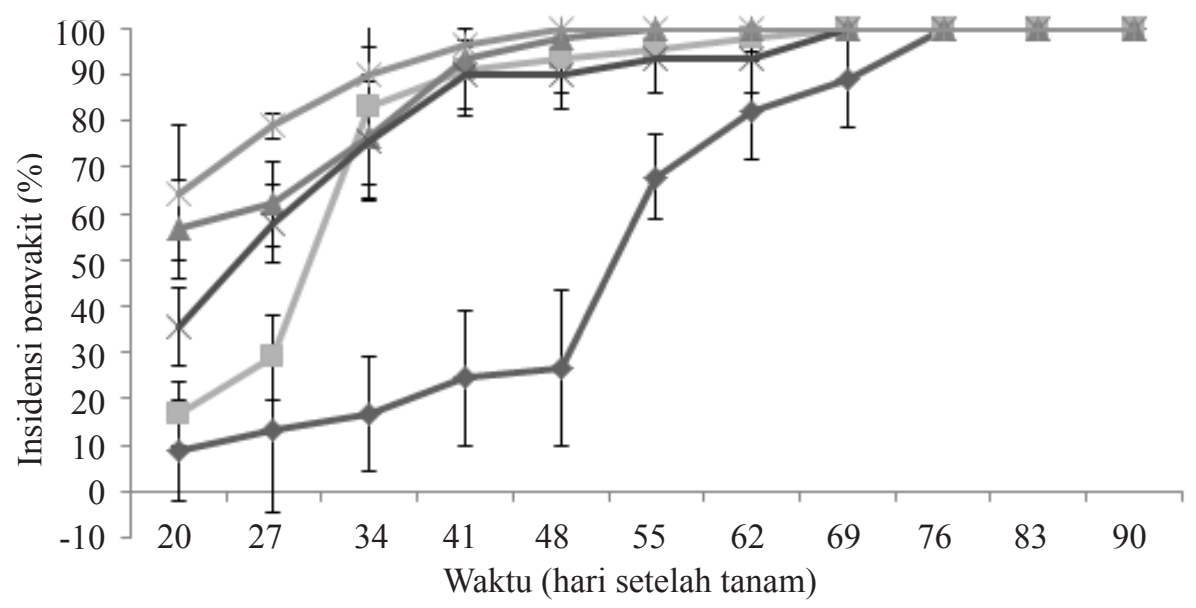

Gambar 2 Perkembangan insidensi penyakit hawar daun bakteri (\%) pada jenis padi yang ditanam. $\leftarrow$, galur padi X; $-\leftarrow$, varietas Inpari $30 ; \rightarrow$, varietas Situbagendit; $\leftarrow$, varietas Cibogo; $\cdots$, varietas Luk-ulo.

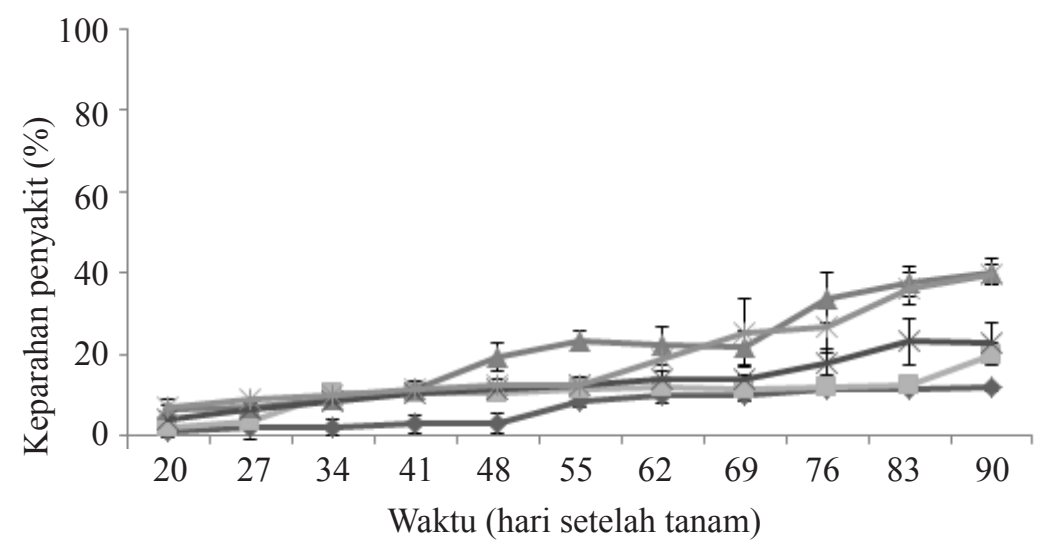

Gambar 3 Perkembangan keparahan penyakit hawar daun bakteri (\%) pada jenis padi yang

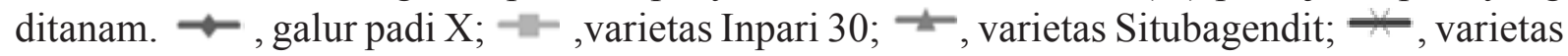
Cibogo; $\cdots$, varietas Luk-ulo.

Padi varietas Situbagendit dan Luk-ulo memiliki jumlah rata-rata anakan terbanyak, yaitu berturut-turut 27 per rumpun dan 26 per rumpun (Tabel 1). Jumlah anakan yang banyak dapat mempengaruhi nilai IP dan KP HDB.

\section{Ketahanan Tanaman terhadap Penyakit HBD}

Ketahanan tanaman pada fase vegetatif berbeda dengan fase generatif, meskipun ada kalanya sama. Berdasarkan nilai IP pada fase vegetatif, hanya tanaman padi galur padi $X$ saja yang tahan terhadap penyakit HDB. Padi var. Inpari 30, Situbagendit, Cibogo, dan Luk-ulo semuanya rentan. Namun setelah memasuki fase generatif, galur padi $X$ yang semula tahan berubah menjadi rentan sehingga pada fase ini semua varietas dan galur yang diuji tergolong tanaman yang rentan (Tabel 2).
Berdasarkan nilai KP, ketahanan terbaik dimiliki padi galur $\mathrm{X}$, yaitu tahan pada fase vegetatif dan agak tahan pada fase generatif. Padi var. Situbagendit dan Luk-ulo samasama agak rentan pada fase vegetatif, namun berubah menjadi rentan pada fase generatif. Berdasarkan pada IP dan KP, padi galur X yang semula tahan menjadi agak tahan pada fase generatif (Tabel 2).

\section{PEMBAHASAN}

Xanthomonas oryzae merupakan patogen yang dapat menginfeksi tanaman padi pada semua fase pertumbuhan. Pada percobaan ini, penyakit HDB sudah ditemukan pada semua varietas dan galur yang diuji pada $20 \mathrm{HST}$. Ciri khas dari gejala penyakit HDB pada 
Tabel 1 Rata-rata jumlah anakan per rumpun pada 42 HST.

\begin{tabular}{lc}
\hline Genotipe padi & Jumlah anakan ${ }^{\text {a) }}$ \\
\hline Galur X & $20 \pm 0.55$ \\
Var. Inpari 30 & $22 \pm 1.35$ \\
Var. Situbagendit & $27 \pm 0.65$ \\
Var. Cibogo & $23 \pm 2.36$ \\
Var. Luk-ulo & $26 \pm 0.65$ \\
\hline
\end{tabular}

a)diperoleh dari 90 rumpun tanaman pada 5 petak sampel setiap varietas yang diamati

Tabel 2 Kategori ketahanan padi berdasarkan nilai IP (\%) dan KP (\%)

\begin{tabular}{|c|c|c|c|c|c|c|}
\hline \multirow{2}{*}{ Varietas padi } & \multicolumn{2}{|c|}{ Berdasarkan IP (\%)* } & \multicolumn{2}{|c|}{ Berdasarkan KP (\%)** } & \multicolumn{2}{|c|}{ Ketahanan varietas*** } \\
\hline & vegetatif & generatif & vegetatif & generatif & vegetatif & generatif \\
\hline Galur X & $\mathrm{T}$ & $\mathrm{R}$ & $\mathrm{T}$ & AT & $\mathrm{T}^{2)}$ & $\mathrm{AT}^{1)}$ \\
\hline Var. Inpari 30 & $\mathrm{R}$ & $\mathrm{R}$ & AT & AR & $\mathrm{AT}^{1)}$ & AR 1) \\
\hline Var. Situbagendit & $\mathrm{R}$ & $\mathrm{R}$ & AR & $\mathrm{R}$ & AR 1) & $\mathrm{R}^{2)}$ \\
\hline Var. Cibogo & $\mathrm{R}$ & $\mathrm{R}$ & AT & AR & $\mathrm{AT}^{1)}$ & $\mathrm{AR}^{1)}$ \\
\hline Var. Luk-ulo & $\mathrm{R}$ & $\mathrm{R}$ & AR & $\mathrm{R}$ & $\mathrm{AR}^{1)}$ & $\mathrm{R}^{2)}$ \\
\hline
\end{tabular}

IP, insidensi penyakit; KP, keparahan penyakit

* kriteria ketahanan mengacu pada : ketahanan penyakit dengan gejala sistemik (PCARRD 1985).

** kriteria ketahanan mengacu pada : standart evaluation system IRRI (IRRI 1994).

*** kriteria ketahanan mengacu: berdasarkan IP dan KP: 1) berdasarkan KP; 2) berdasarkan IP dan KP

R: rentan, AR: agak rentan, AT: agak tahan, T: tahan

varietas dan galur yang diuji ialah adanya perubahan warna daun menjadi keabu-abuan dan agak mengering yang dimulai dari pucuk atau tepian daun. Hal tersebut dikarenakan sebagian besar $X$. oryzae menginfeksi tanaman dengan melakukan penetrasi ke dalam jaringan tanaman melalui hidatoda yang terletak di tepian daun (IRRI 2014). Setelah masuk kedalam jaringan tanaman, X. oryzae akan bersifat sistemik dan menyebar keseluruh jaringan tanaman melalui pembuluh xilem.

Menurut Wahyudi et al. (2011) gejala kresek adalah gejala HDB pada fase vegetatif dan merupakan gejala yang paling merusak pada tanaman padi. Pada varietas yang rentan, gejala tersebut dapat berkembang hingga seluruh daun menjadi kering. Tingkatan terakhir dari gejala kresek ialah membusuknya tanaman atau dikenal dengan penyakit lodoh. Selama percobaan dilakukan, gejala kresek dengan nilai KP tinggi yang menyebabkan kematian pada tanaman tidak ditemukan. Meskipun semua varietas yang diuji mencapai IP $100 \%$. Penyakit HDB berada pada ambang kerusakanapabilaKPmencapai 20\% padaumur 2 minggu sebelum panen dan setiap kenaikan
KP 10\% dari nilai tersebut akan diikuti dengan peningkatan kehilangan hasil 5-7\% (Sudir dan Kadir 2012). Hal ini juga terjadi pada var. Situbagendit yang mencapai ambang kerusakan terparah dari varietas lain sejak 55 HST dengan KP 23.33\%. Keparahan penyakit tersebut juga dapat digunakan sebagai bahan studi epidemi penyakit.

Waktu percobaan yang dilakukan pada musim hujan diduga berpengaruh terhadap nilai IP dan KP yang diperoleh, hal tersebut dikarenakan percikan air hujan adalah medium penularan yang efektif untuk penyakit ini (Sudir dan Kadir et al. 2012) sehingga berpengaruh terhadap IP yang mengalami peningkatan dengan cepat. Di samping hujan, kerapatan anakan juga mempengaruhi nilai IP yang tinggi. Kerapatan tanaman selain mempengaruhi kelembapan juga akan mempermudah penularan penyakit dari satu tanaman ke tanaman yang lain. Oleh karena itu, KP dan IP tertinggi terjadi pada kedua varietas tersebut.

Riwayat semua lahan yang digunakan ditanami padi-padi-tembakau, namun di sekitar lahan yang digunakan selalu ada 
tanaman padi. Hal tersebut memungkinkan bagi $X$. oryzae untuk tetap berada pada lokasi tersebut. $X$. oryzae merupakan bakteri yang dapat bertahan pada tanah hingga 3 bulan (Joko dan Wibisono 2007). Selain itu sisa tanaman sakit dan gulma seperti Zezania latifolia, Cyperus rotundus, dan Leptochloa chinensis juga merupakan inang alternatif bagi bakteri tersebut (Djatmiko et al. 2011).

Fase vegetatif pada tanaman padi juga merupakan fase yang mudah diinfeksi dan merupakan fase rentan terhadap penyakit HDB (Djatmiko dan Fatichin 2009). Oleh karena itu, penurunan nilai ketahanan pada fase generatif oleh semua varietas dan galur yang diuji merupakan dampak dari infeksi $X$. oryzae pada fase vegetatif yang terus berkembang di dalam jaringan tanaman. Dengan demikian, saat yang tepat untuk mengukur ketahanan tanaman ialah fase vegetatif.

Berdasarkan IP dan KP, padi var. Situbagendit yang agak tahan (AT) menjadi agak rentan (AR) pada fase vegetatif dan rentan (R) pada fase generatif, var. Luk-ulo yang tahan (T) menjadi AR pada fase vegetatif dan $\mathrm{R}$ pada fase generatif, sedangkan var. Cibogo yang juga tergolong AT menjadi AR pada fase generatif. Penurunan ketahanan ini diduga merupakan akibat dari galur $X$. oryzae yang lebih virulen dibandingkan dengan jenis galur yang dapat ditoleransi oleh varietas tersebut. Hal itu dikarenakan ketiga varietas tersebut hanya memiliki spesifikasi ketahanan terhadap bakteri galur III dan IV (BPTP 2011). Setiap galur dari $X$. oryzae memiliki kemampuan yang berbeda dalam menginfeksi tanaman. Patahnya ketahanan tanaman padi terhadap $X$. oryzae merupakan akibat dari sifat ketahanannya yang hanya diwariskan oleh satu gen mayor atau dikenal dengan ketahanan monogenik (Winandari 2014). Varietas Inpari 30 merupakan varietas yang baru dirilis pada tahun 2012 dan belum pernah ditanam di daerah Wirolegi sehingga menjadi varietas baru pada daerah itu. Varietas Inpari 30 yang tergolong AR menurut BPPP (2014b), pada percobaan ini menjadi AT pada fase vegetatif dan AR pada fase generatif. Diduga perubahan ketahanan varietas ini dikarenakan oleh jumlah anakannya yang tergolong sedikit (20 anakan per rumpun).

Pada tulisan ini, ketahanan tanaman disajikan berdasarkan pada nilai IP dan KP dengan sumber acuan yang berbeda untuk mencari tahu varietas mana yang akan dipilih dalam hal ketahanannya terhadap penyakit HBD untuk ditanam lagi pada musim penghujan. IP pada dasarnya, lebih mencerminkan penyebaran penyakit pada lahan tersebut, yaitu menunjukkan pertambahan tanaman yang terinfeksi pada periode pengamatan berikutnya. Sedangkan KP mencerminkan perkembangan penyakit pada tiap rumpun tanaman, sehingga dapat diketahui tingkat kerusakan pada tanaman yang berpotensi mencapai ambang kerusakan.

\section{DAFTAR PUSTAKA}

[BPPP] Balai Penelitian dan Pengembangan Pertanian. 2014a. Kalender Tanam Terpadu. Versi 2.0 MH Oktober 2014-Maret 2015 Kabupaten Jember Provinsi Jawa Timur. Jakarta (ID): Kementrian Pertanian RI.

[BPPP] Balai Penelitian dan Pengembangan Pertanian. 2014b. Varietas Inpari 30. http:// litbang.pertanian.go.id/varietas/one/848/. htm [diakses 19 April 2015].

[BPTP] Balai Pengkajian Teknologi Pertanian. 2011. Deskripsi Sederhana Varietas Padi Tahun 1978-2010. Jakarta (ID): Kementrian Pertanian RI.

Djatmiko HA, Fatichin. 2009. Ketahanan dua puluh satu varietas padi terhadap penyakit hawar daun bakteri. J HPT Tropika. 9(2):169-173.

Djatmko HA, Prakoso B, Prihatiningsih N. 2011. Penentuan patotipe dan keragaman genetik Xanthomonas oryzae pv. oryzae pada tanaman padi di wilayah karesidenan Banyumas. J HPT Tropika. 11(1):35-46.

Herlina L, Silitonga TS. 2011. Seleksi lapang ketahanan beberapa varietas padi terhadap infeksi hawar daun bakteri strain IV dan VIII. J Plasma Nutfah. 17(2):80-87. 
[IRRI] International Rice Research Institute. Winandari OP, Tjahjoleksono A, Utami DW. 1994. A Manual of Rice Seed Health 2014. Identifikasi marka gen ketahanan Testing. Los Banos, Philippines: IRRI.

[IRRI] International Rice Research Institute. 2014. Bacterial blight. http://www.Knowledgebank.Irri.Org/ Ricebreedingcourse/Breeding_For Disease_Resistance_Blight [diakses 30 Desember 2014].

Joko S, Wibisono I. 2007. Hama dan Penyakit Tanaman Pangan. Yogyakarta (ID): PT. Cipta Aji Parama.

Khaeruni A, Rahim A, Syair, Adriani. 2014. Induksi ketahanan terhadap penyakit hawar daun bakteri pada tanaman padi di lapangan menggunakan Rizobakteri hawar daun bakteri pada galur padi introduksi dan galur dihaploid. J HPT Tropika. 14(2):101-109.

Sudir NB, Kadir TS. 2012. Epidemiologi, patotipe, dan strategi pengendalian penyakit hawar daun bakteri pada tanaman padi. J IPTEK Tanaman Pangan. 7(2):7287.

Wahyudi AT, Meliah S, Nawangsih AA. 2011. Xanthomonas oryzae pv. oryzae bakteri penyebab hawar daun pada padi: isolasi, karakterisasi, dan telaah mutagenesis dengan transposon. J Sains. 15(1):89-96. indigenos. J HPT Tropika. 14(1):57-63.

[PCARRD] Philippine Council for Agriculture and Resources Research and Development. 1985. Research Techniques in Crops. Book series No. 35. Los Banos (PH): Philippines National Science and Technology Authority. 